\title{
Vernaculares: três momentos (?)
}

Hilton Costa ${ }^{l}$

Aprendizado. Esta mui provavelmente é a palavra que melhor define minhas passagens anteriores na Revista Vernáculo, bem como a atual.

A primeira passagem foi entre 2000 e 2002, foi de modo indireto, divulgando a Revista, colaborando pontualmente em uma tarefa ou outra, o convite para participar partiu das pessoas que idealizaram a Revista Allan Oliveira, Fernando Nicolazzi, Laís H.Telles, Rafael F. Benthien, Maurício Ouyama e Victor A. Graciotto, Rodrigo Turin. Este momento foi interessante para aprender como funcionava o processo de captação de recursos para a impressão do periódico - sim ele era impresso -, de preparação dos originais, a construção de chamadas para artigos. E substancialmente foi-se aprendendo o trabalho acadêmico em equipe, o ouvir e o saber buscar o espaço para ser ouvido.

A segunda passagem ocorreu a partir de 2004 (não tenho muita certeza, mas acho que foi), quando pude trabalhar mais diretamente na

Graduado em História e em Ciências Sociais pela UFPR, Mestre em História, UFRGS, Doutor em História, UFPR. 
organização da Revista, da busca por patrocínios, da negociação com as pessoas que pudessem vir a colaborar na impressão fornecendo o serviço gráfico... Esta passagem foi intensa e curta, pois em 2006/2007 se bem me recordo já estava bastante afastado das atividades da Vernáculo. Neste curto espaço de tempo o aprendizado acerca das agruras do empreendimento cultural foi enorme, como é difícil captar recursos, oferecer a contrapartida a quem investe e "justificar" comercialmente um empreendimento voltado ao público acadêmico... Experiência deveras interessante. Nesta passagem também foi possível trabalhar mais diretamente com Jonas Wilson Pegoraro algo da mais alta importância, pois se aprendeu e ou se teve a certeza que arrojo “empresarial” é coisa das mais necessárias e relevantes para os empreendimentos acadêmicos.

A terceira passagem teve início em algum momento entre 2010 de 2012 e segue até o presente momento. Esta surgiu de um momento particularmente sui generis em meio ao trabalho para a elaboração da minha tese de doutorado. Obtive a informação que a Vernáculo ainda existia. A informação chegou a mim via dois colegas do curso de pósgraduação em História da UFPR - Leonardo Brandão Barleta e Natally Nobre. O primeiro estava envolvido com a Revista naquele momento (e continua) e a segunda havia participado. Em conversas com o Leonardo resolvi me informar novamente das coisas da Vernáculo. 
A Revista estava desperiodizada, havia artigos por avaliar, equipe editorial e conselho a reorganizar. No entanto, a Vernáculo já estava toda digitalizada e disponível on-line, resultado do trabalho da Natally Nobre e do Leonardo. O periódico havia feito à transição da base impressa, que já mostrava inviável em 2006/7 (a dificuldade de captar recursos para impressão, a falta de condições para criar uma dinâmica de distribuição, o fato de não se ter um local para estocagem dos exemplares impressos e mais algumas outras situações depunham contra o formato impresso), para o formato digital. A passagem de um formato para outro já era ponto de pauta das pessoas envolvidas com a Vernáculo em momentos anteriores a segunda metade da primeira década do século XXI, contudo a execução não se efetivara muito pela limitação técnica da época.

Atualizado da situação da Revista praticamente me escalei para voltar a participar da equipe editorial. Desta feita, penso que em algum momento de 2011 ou 2012 fizemos algumas reuniões para tentar reperiodizar a Vernáculo e pensar novas estratégias de ação (divulgação, captação de artigos, etc.) apesar de várias boas ideias e outras ótimas ideias, em termos práticos pouca coisa foi realizada. Aí em uma conversa com Leonardo Barleta numa caminhada regada a cerveja artesanal rumo a um jogo de futebol - decidimos vamos fazer. E aí um novo horizonte de aprendizado se apresentou para mim: aprender a trabalhar na plataforma digital; aprender a como reorganizar um 
periódico com as características da Revista Vernáculo, voltada para a produção de discentes de graduação, foi algo deveras instigante; a formação da equipe editorial, do conselho editorial à busca de discentes de graduação para a equipe editorial foi uma tarefa das mais interessantes, um aprendizado e tanto.

Entre idas e vindas é viável afirmar que cada momento de participação foi, e provavelmente continuará sendo de intenso aprendizado. Aprendizado das técnicas necessárias para se trabalhar na plataforma digital, das melhores formas de relacionamento possível com as pessoas que colaboram com sua produção intelectual para o prosseguimento do periódico e substancialmente o aprendizado constante do trabalho em equipe. 